\title{
Meslingutbrudd ved økt reisevirksomhet og lav vaksinedekning
}

\author{
Vinteren og våren 2011 var det en rekke tilfeller av meslinger i Oslo, fordelt på minst tre forskjellige utbrudd. \\ I alt 24 ble syke, og de fleste måtte innlegges i sykehus. Nesten alle var uvaksinert.
}

Dette er et relativt stort antall i dagens Norge. Meslinger er blitt en forholdsvis sjelden sykdom etter at MMR-vaksine ble innført i barnevaksinasjonsprogrammet i 1969. I perioden $2001-10$ ble det i gjennomsnitt registrert fem tilfeller per år i MSIS-systemet. Til sammenlikning ble det i perioden 1959-68 i gjennomsnitt meldt rundt 21000 tilfeller per år (1).

Samtidig melder WHO om flere utbrudd av meslinger i Europa, med en særlig økning etter 2009 (2). I 2011 var det meslingutbrudd i 36 av 53 land i Europa. Frankrike hadde det største utbruddet, med over 14000 smittede. Dette har skjedd til tross for at alle land i Europa anbefaler to doser vaksine mot meslinger i sine vaksinasjonsprogrammer, og det står i kontrast til målsettingen om å utrydde meslinger i Europa innen 2015 (2).

\section{Utbrudd i lommer av uvaksinerte}

Den viktigste årsaken til utbruddene i Europa har vært motstand mot MMRvaksinen i enkelte miljøer. Dårlig tilgang på helsetjenester har også medvirket noen steder (3). Utbruddene har kommet i grupper med lav vaksinasjonsdekning, slik som

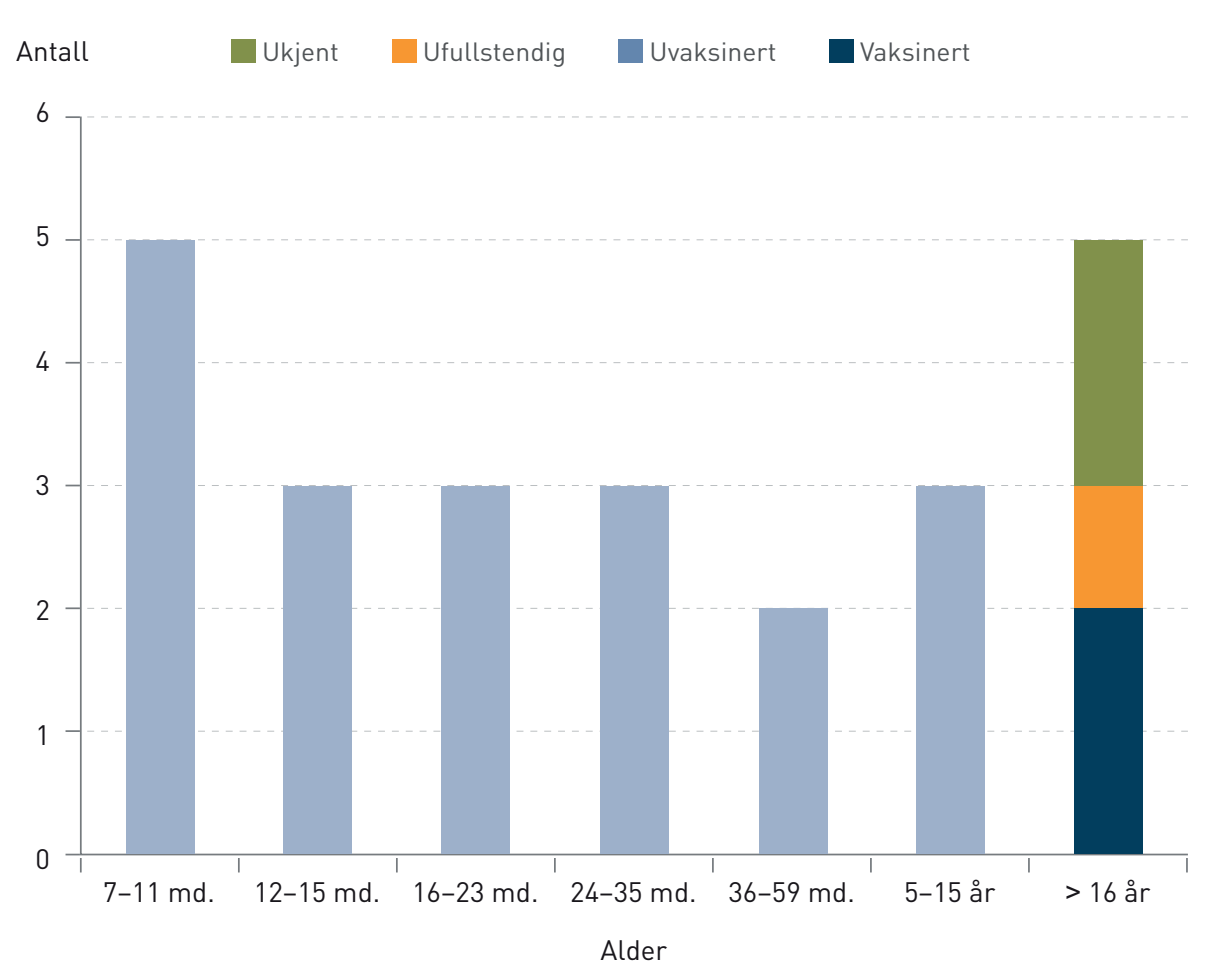

Figur 1 Meslingutbruddene i Oslo januar-mai 2011. Alder og vaksinasjonsstatus for 24 syke romfolk og andre reisende, antroposofiske miljøer og enkelte religiøse grupper (3). Meslinger er blant de sykdommer som smitter lettest fra person til person. Kommer det meslingsmitte inn i et miljø med lav vaksinasjonsdekning, kan mange bli syke. Innvandrermiljøer med lav dekning og mye kontakt med høyendemiske hjemland er spesielt utsatt for smitte.

Verdens helseorganisasjon anslår at 95\% dekning er nødvendig for å eliminere meslinger. De siste årene har Oslo hatt en vaksinasjonsdekning for meslinger som er litt under landsgjennomsnittet, med 90\% for toåringer født i 2008 og $93 \%$ for dem født i 2007. Bydel Gamle Oslo har hatt den laveste dekningen, med henholdsvis $85 \%$ for barn født i 2008 og $88 \%$ for barn født i 2007. Bydelen har den største konsentrasjonen av somaliere i Oslo, både absolutt og relativt. I 2011 hadde $12 \%$ av barna under seks år i denne bydelen somaliske foreldre (4). Helsetjenesten har hatt inntrykk av dårlig dekning for MMR-vaksine $\mathrm{i}$ denne gruppen. Det er imidlertid ikke mulig å få ut tall for dekningsgrad basert på fødeland eller etnisitet i SYSVAK. 
i tiltak for autistiske barn. Også der er det meldt om vaksinasjonsskepsis blant foreldrene, og i mars 2011 ble det meldt om et meslingutbrudd blant somaliske barn i delstaten (8).

\section{Tiltak i bydel Gamle Oslo}

Da det første tilfellet ble meldt, ble det straks gjennomført hjemmebesøk med smitteoppsporing, prøvetaking og tilbud om vaksine til de uvaksinerte. Da det kom flere tilfeller med samme adresse, ble det gjennomført en dør-til-dør-aksjon i blok-

\section{«Dersom alle over 15 måneder hadde vært vaksinert, kunne 21 av de 24 tilfellene vært unngått»}

ken, med informasjonsskriv på norsk og somali. Berørte barnehager og skoler ble gitt generell informasjon, og barnas vaksinasjonsstatus ble sjekket. Barn ned til ni måneders alder fikk tilbud om vaksinasjon. Det ble arrangert et møte hvor det ble gitt informasjon om meslinger og MMR-vaksine på somali. Dette var godt besøkt, og 25 barn ble vaksinert i ukene etterpå. Oslo kommune har senere laget en brosjyre på norsk og somali som alle helsestasjoner kan dele ut til somaliske foreldre.

\section{Bør tidspunktet}

\section{for MMR-vaksinering endres?}

Åtte av de syke barna i Oslo var under 15 måneder. Det reiser spørsmålet om vi i Norge bør fremskynde tidspunktet for første MMR-vaksine. I mange land i Europa gir man meslingvaksine ved 12 måneders alder, og Frankrike anbefaler vaksine ved ni måneders alder for barnehagebarn. Verdens helseorganisasjon anbefaler vaksinering ved ni måneders alder i høyendemiske land og ved 12 måneders alder i lavendemiske (9). Våre naboland har foreløpig holdt fast ved tidspunktet for første MMR-dose (15-18 måneder).

Når vi følger smitteveiene i dette materialet, ser det imidlertid ut til at tidligere vaksinering ville betydd langt mindre enn bedre dekning. Dersom alle over 15 måneder hadde vært vaksinert, kunne 21 av de 24 tilfellene vært unngått. Til sammenlikning ville man dersom man hadde flyttet tidspunktet for vaksinasjon til 12 måneders alder, uten bedring av vaksinasjonsstatus for øvrig, bare kunnet unngå de tre tilfellene der barna var i alderen 12-15 måneder. I tillegg kan nevnes at det er kommet data fra utbrudd i Canada som antyder at vaksinasjon i 12-14-månedersalderen kanskje gir dårligere beskyttelse på lang sikt enn vaksinasjon ved 15 måneders alder eller senere, selv om man totalt gir to doser (10).

I dette materialet ville det altså utgjort stor forskjell dersom vi hadde klart å gjennomføre det eksisterende vaksinasjonsprogrammet fullt ut, mens det å flytte tidspunkt for vaksineringen bare ville gitt marginal gevinst.

Blant helsepersonell som ble smittet, var det varierende vaksinasjonsstatus. I sykehus bør det være en oppgave for bedriftshelsetjenesten å sørge for at personalet i utsatte avdelinger som pediatri og infeksjonsmedisin er fullvaksinert mot meslinger. Boostervaksinasjon kan også vurderes. Likeså bør alle allmennleger og alle medisin- og sykepleiestudenter sørge for å være vaksinert (11).

\section{Reise til høyendemiske områder}

Vårt inntrykk er at vaksinasjonsdekningen for MMR-vaksine blant somaliske barn i Oslo er lav. Dersom dette stemmer, er denne gruppen ekstra utsatt for smitte, for eksempel ved kontakt med sitt høyendemiske hjemland. Det var mange tusen meslingtilfeller i Somalia i fjor, og store utbrudd i flyktningleire i nabolandene Kenya og Etiopia. I Somalia er det svært lav dekning for vaksine mot meslinger, WHO anslår den til $24 \%$. Dekningsgraden er også relativt lav i Kenya og Etiopia, med henholdsvis $74 \%$ og $75 \%$ (12). Sett i lys av at meslinger er en svært smittsom sykdom, er det ekstra viktig at personer som har kontakt med høyendemiske land er beskyttet med vaksine. Uvaksinerte bør antakelig frarådes å reise.

Omfanget av kulturspesifikk motstand mot vaksine kan belyses bedre dersom man kobler SYSVAK-data med folkeregisteret for å se på vaksinasjonsdekning i relasjon til etnisk bakgrunn, noe vi mener bør gjøres. Bedre tilpasset informasjon til spesielle grupper kan være nødvendig for å unngå hyppigere utbrudd av meslinger i lommer av uvaksinerte.

\section{Tore Wælgaard Steen}

tore.steen@hel.oslo.kommune.no

Helseetaten

Oslo kommune

\section{Trude M. Arnesen}

Bydel Gamle Oslo

\section{Susanne Gjeruldsen Dudman}

Avdeling for virologi

Nasjonalt folkehelseinstitutt

Ann-Louise Gustafsson

Bydel Gamle Oslo

Astrid Rojahn

Barnemedisinsk avdeling

Oslo universitetssykehus

\section{Karin Rønning}

Avdeling for infeksjonsovervåking

Nasjonalt folkehelseinstitutt
Harald Vallgårda

Legevakten

Oslo kommune

\section{Kirsti Vainio}

Avdeling for virologi

Nasjonalt folkehelseinstitutt

Tore Wælgaard Steen (f. 1950) er dr.med og spesialist i samfunnsmedisin. Han er smittevernoverlege i Oslo. Tidligere var han kommunelege i Vågan, assisterende fylkeslege i Vest-Agder samt distriktslege og rådgiver i Botswana.

Forfatter har fylt ut ICMJE-skjemaet og oppgir ingen interessekonflikter.

Trude Arnesen (f. 1967) er dr.med. og master of public health. Hun er bydelsoverlege i Gamle Oslo og styremedlem i NORSAM.

Forfatter har fylt ut ICMJE-skjemaet og oppgir ingen interessekonflikter.

Susanne Gjeruldsen Dudman (f. 1964) er dr.med. og spesialist i medisinsk mikrobiologi. Hun er overlege ved Avdeling for virologi ved Nasjonalt folkehelseinstitutt.

Forfatter har fylt ut ICMJE-skjemaet og oppgir ingen interessekonflikter.

Ann-Louise Gustafsson (f. 1960) er overhelsesøster i bydel Gamle Oslo. Hun har videreutdanning i folkehelsevitenskap og administrasjon/ ledelse.

Forfatter har fylt ut ICMJE-skjemaet og oppgir ingen interessekonflikter.

Astrid Rojahn (f. 1967) er spesialist i pediatri, med spesialkompetanse i infeksjonssykdommer. Hun er overlege ved Barneklinikken, Oslo universitetssykehus, Ullevål, medlem av tuberkulosekomiteen og styremedlem i interessegruppen for pediatriske infeksjonssykdommer Legeforeningen.

Forfatter har fylt ut ICMJE-skjemaet og oppgir ingen interessekonflikter.

Karin Rønning (f. 1953) er spesialist i samfunnsmedisin og har en mastergrad i helseadministrasjon. Hun arbeider med infeksjonsovervåking på Folkehelseinstituttet.

Forfatter har fylt ut ICMJE-skjemaet og oppgir ingen interessekonflikter.

Harald Vallgårda (f. 1958) er seksjonsoverlege ved Legevakten, Oslo kommune. Han var tidligere allmennlege.

Forfatter har fylt ut ICMJE-skjemaet og oppgir ingen interessekonflikter.

Kirsti Vainio (f. 1958) er dr.scient. (ph.d.), seniorforsker og fagansvarlig for meslinger, rubella og kusma ved Avdeling for virologi, Folkehelseinstituttet. Avdelingen er et nasjonalt WHOlaboratorium for meslinger og rubella og nasjonalt referanselaboratorium for meslinger, rubella og kusma.

Forfatter har fylt ut ICMJE-skjemaet og oppgir ingen interessekonflikter. 


\section{Litteratur}

1. Martin PR. Meslinger i Norge. Epidemiologien før og etter innføring av vaksinasjon. Tidsskr Nor Lægeforen 1989; 109: 2984-8.

2. Strategic plan for measles and congenital rubella infection in the European Region of WHO. København: WHO Regional Office for Europe, 2003.

3. Increased transmission and outbreaks of measles, European Region, 2011. Wkly Epidemiol Rec 2011. 86: $559-64$.

4. Oslostatistikken. www.utviklings-ogkompetanseetaten.oslo.kommune.no/ oslostatistikken/ (12.3.2012)

5. Vainio K, Rønning K, Steen TW et al. Ongoing outbreak of measles in Oslo, Norway, JanuaryFebruary 2011. Euro Surveill 2011; 16. pii: 19804.

6. Smeeth L, Cook C. Fombonne E et al. MMR vaccination and pervasive developmental disorders: a case-control study, Lancet 2004: 364: $963-9$.

7. Barnevik-Olsson M, Gillberg C, Fernell E. Prevalence of autism in children of Somali origin living in Stockholm: brief report of an at-risk population. Dev Med Child Neurol 2010; 52: 1167-8.

8. Centers for Disease Control and Prevention (CDC). Notes from the field: measles outbreak - Hennepin County, Minnesota, February-March 2011. MMWR Morb Mortal Wkly Rep 2011; 60: 421

9. Measles vaccines: WHO position paper. Wkly Epidemiol Rec 2009; 84: 349-60.

10. Hampton T. Outbreaks spur measles vaccine studies. JAMA 2011; 306: 2440-2

11. Botelho-Nevers E, Chevereau L, Brouqui P. Spotlight on measles 2010: measles in healthcare workers - vaccination should be revisited. Euro Surveill 2010; 15. pii: 19687.

12. Public health risk assessment and interventions. The Horn of Africa: drought and famine crisis. WHO/HSE/GAR/DCE/2011.3. Genève: World Health Organization, 2011.

Mottatt 26.10. 2011, første revisjon innsendt 8.2. 2012, godkjent 22.3. 2012. Medisinsk redaktør Siri Lunde. 